\title{
GROWTH AND EXOPOLYSACCHARIDE PRODUCTION BY STREPTOCOCCUS THERMOPHILUS ST1 IN SKIM MILK
}

\author{
Tiehua Zhang ${ }^{1,2}$, Chunhong Zhang ${ }^{2}$, Shengyu Li ${ }^{1}$, Yanchun Zhang ${ }^{1}$, Zhennai Yang ${ }^{1,3 *}$
}

${ }^{1}$ Center of Agro-food Technology, Northeast Agricultural Research Center of China, Changchun 130033 P. R. China; ${ }^{2}$ College of Light Industry and Economics \& Management, Jilin University, Changchun 130062 P. R. China; ${ }^{3}$ College of Biological and Agricultural Engineering, Jilin University, Changchun 130025 P. R. China.

Submitted: March 28, 2010; Approved: May 23, 2011.

\begin{abstract}
To analyze the exopolysaccharide (EPS) production by Streptococcus thermophilus ST1, cultures were cultivated in $10 \%(\mathrm{w} / \mathrm{v})$ reconstituted skim milk under different growth conditions including various temperatures and $\mathrm{pHs}$ of growth medium, supplementation of the medium with various carbon sources (glucose, lactose, sucrose, galactose and fructose) and nitrogen source (whey protein concentrate, or WPC). The results showed that most EPS production by strain ST1 was obtained at a temperature $\left(42^{\circ} \mathrm{C}\right)$ and $\mathrm{pH}$ (6.5) optimal for its growth. Supplementation of the skim milk medium with either carbohydrates or WPC increased both growth and polymer formation by different extents, with sucrose being most effective among the carbon sources tested. Under the optimal cultural conditions, i.e. $\mathrm{pH} 6.5,42^{\circ} \mathrm{C}$ with $2 \%(\mathrm{w} / \mathrm{v})$ sucrose and $0.5 \%(\mathrm{w} / \mathrm{v}) \mathrm{WPC}, 135.80 \mathrm{mg} \mathrm{l}^{-1}$ of EPS was produced by strain ST1. The monosaccharide composition of the EPS was determined to be glucose and galactose (2:1), and the molecular mass of the EPS was $3.97 \times$ $10^{6} \mathrm{Da}$. The aqueous solution of the EPS at $1 \%(\mathrm{w} / \mathrm{v})$ showed relatively high viscosity, indicating the potential of this EPS-producing $S$. thermophilus strain for applications in the improvement of physical properties of fermented milk products.
\end{abstract}

Key words: Exopolysaccharide, Streptococcus thermophilus ST1, Skim milk

\section{INTRODUCTION}

There has been an increasing interest in the exopolysaccharides (EPSs) produced by lactic acid bacteria (LAB) during the last decade. These biopolymers may function as viscosifiers, texturizers, or emulsifying agents to improve the texture and consistency of fermented milk (35). EPSs produced by LAB have been shown to play an important role in the prevention of syneresis (whey separation), a common problem in yogurt manufacturing (15). In situ production of EPSs by yogurt bacteria has been suggested to be used as an alternative to the addition of stabilizers, e.g. animal

*Corresponding Author. Mailing address: Center of Agro-food Technology, Northeast Agricultural Research Center of China, No. 1363 Cai-Yu Street, Changchun, Jilin Province, 130033 P.R. China.; Tel.: 86-431-87063148 Fax: 86-431-87063075.; Email: zyang@cjaas.com 
hydrocolloids (gelatin and casein) or chemically modified plant carbohydrates (starch, pectin and guar gum) (36). Since LAB strains are generally food-grade microorganisms with a GRAS (Generally Recognised As Safe) status, the use of EPSproducing $\mathrm{LAB}$ in food fermentation could result in safe and natural products with improved stability (9). All-natural products have become increasingly popular during the recent years (31).

The characteristics of EPS production by LAB vary considerably with the strains with respect to EPS yield, rheological properties, monosaccharide composition and structure of EPS $(28,38)$. Physiologically, EPS synthesis by $\mathrm{LAB}$ is influenced by many factors, e.g. temperature, $\mathrm{pH}$, and components of growth medium and fermentation time, among others (9,27). Streptococcus thermophilus strains have been reported to produce EPSs from 50 to $350 \mathrm{mg} \mathrm{l}^{-1}$ (3). $S$. thermophilus LY03 was shown to produce the highest amount of EPS at $42^{\circ} \mathrm{C}$ and at pH 6.2 (10), and it produced more EPS with lactose than glucose as the carbon source (7). Looijesteijn and Hugenholtz (21) found a higher production of EPS by Lactococcus lactis spp. cremoris B40 with glucose than when fructose was used as substrate. For some $S$. thermophilus strains used in a protocooperative yoghurt culture, the presence of L. delbrueckii subsp. bulgaricus was necessary to ensure their proper growth and EPS production $(35,25)$. Supplementation of the skim milk medium with whey protein concentrate (WPC) or whey protein hydrolysates increased EPS production by $S$. thermophilus ST111 $(32,35)$. The use of WPC increased buffering capacity of the medium, thus decreasing the acidic effects on EPS production during fermentation (9).

During our studies on the EPS production by LAB, we found in the LAB collection of our laboratory an EPSproducing strain, $S$. thermophilus ST1 that produced a viscous culture when grown in skim milk. Since $S$. thermophilus is commonly used as one of the starter strains for yoghurt manufacturing, it would be interesting to study the characteristics of EPS production in view of improving the physical properties of yoghurt by using EPS-producing strains. Therefore, the present work was carried out to study the effect of different cultural conditions on the EPS production by $S$. thermophilus ST1, aiming to improve the EPS yield of this strain for possible dairy applications. In addition, the EPS was isolated, and the monosaccharide composition, molecular mass and viscosity properties of the EPS were studied.

\section{MATERIALS AND METHODS}

\section{Bacterial strain}

S. thermophilus ST1 obtained from the Culture Collection of NARCC (Northeast Agricultural Research Center of China) was used throughout this study. The strain was stored at $-80^{\circ} \mathrm{C}$ in reconstituted skim milk powder at $10 \%(\mathrm{w} / \mathrm{v}$, Fonterra, New Zealand) containing 30\% (v/v) glycerol. S. thermophilus ST1 was propagated three times consecutively using a $1 \%(\mathrm{v} / \mathrm{v})$ inoculum in $10 \%(\mathrm{w} / \mathrm{v})$ skim milk at $42^{\circ} \mathrm{C}$ for $18 \mathrm{~h}$ before use.

\section{Growth experiments}

Batch cultures of $S$. thermophilus ST1 were performed using $10 \%(\mathrm{w} / \mathrm{v})$ skim milk in $1500 \mathrm{ml}$ Erlenmeyer flasks for $40 \mathrm{~h}$, to study the influence of different factors on bacterial growth, acidification and EPS production. The effect of the initial $\mathrm{pH}$ of the medium was studied at $37^{\circ} \mathrm{C}$ with $\mathrm{pH} 5.0,6.0$, 6.5 , and 7.0, the $\mathrm{pH}$ being adjusted with $0.1 \mathrm{M} \mathrm{NaOH}$ and 0.1 $\mathrm{M} \mathrm{HCl}$. The effect of temperature was studied at 30, 37 and $42^{\circ} \mathrm{C}$. The influence of supplementation with $2 \%(\mathrm{w} / \mathrm{v})$ glucose, lactose, sucrose, galactose, fructose or $0.5 \%(\mathrm{w} / \mathrm{v})$ WPC was studied at $42^{\circ} \mathrm{C}$.

For each experiment, a $1 \%$ inoculum of $18 \mathrm{~h}$ grown culture was added to $1000 \mathrm{ml}$ of the medium, and the $\mathrm{pH}$ was allowed to drop freely during bacterial growth. Samples (50 $\mathrm{ml}$ ) were aseptically withdrawn at $0 \mathrm{~h}$ and every $8 \mathrm{~h}$ thereafter to determine the amount of EPS and $\mathrm{pH}$. A fresh sample $(1 \mathrm{ml})$ was also taken for immediate enumeration of the bacterial 
counts by serial decimal dilutions. A $1 \mathrm{ml}$ aliquot of inoculated skim milk was sampled and plated using the pour plating technique. Solidified agar plates were incubated aerobically at $42^{\circ} \mathrm{C}$ for $48 \mathrm{~h}$. A digital display $\mathrm{pH}$ meter (PB-10, Sartorius, Germany) was used to determine $\mathrm{pH}$.

\section{Isolation and analyses of EPS}

After incubation at $42^{\circ} \mathrm{C}$ for $32 \mathrm{~h}$ in $10 \%(\mathrm{w} / \mathrm{v})$ skim milk, cultures $(1000 \mathrm{ml})$ were heated at $100^{\circ} \mathrm{C}$ for $15 \mathrm{~min}$ to inactivate the enzymes potentially capable of polymer degradation, and cells were removed by centrifugation $(10,000$ $\left.\times \mathrm{g}, 10 \mathrm{~min}, 4^{\circ} \mathrm{C}\right)$. The supernatant was precipitated with two volumes of chilled absolute ethanol. After standing overnight at $4{ }^{\circ} \mathrm{C}$, the resultant precipitate was collected by centrifugation $\left(12,000 \times g, 20 \mathrm{~min}, 4^{\circ} \mathrm{C}\right)$, dissolved in distilled water, dialyzed against distilled water at $4^{\circ} \mathrm{C}$ for $24 \mathrm{~h}$, and lyophilized. The lyophilized powder (100 mg) was dissolved in water, loaded onto a DEAE-Cellulose column $(2.6 \times 30 \mathrm{~cm})$, and eluted with distilled water at a flow rate of $1 \mathrm{ml} \mathrm{min}^{-1}$. Fractions were collected every $5 \mathrm{~min}$ and peak fractions containing polysaccharides $(50 \mathrm{ml})$ were pooled, dialyzed and lyophilized. The lyophilized sample $(30 \mathrm{mg})$ was further separated by gel filtration on Sepharose CL-6B column $(2.6 \times 100 \mathrm{~cm})$ (Amersham Pharmacia Biotech, Sweden) eluted with $0.9 \%$

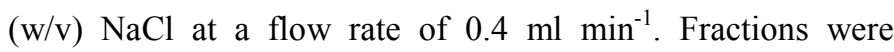
collected every $20 \mathrm{~min}$ and the peak fractions were pooled, dialyzed with water and lyophilized. Fractions were monitored for sugars by a method described by Dubois et al. (12).

The monosaccharide composition of EPS was determined by a method described by Honda et al. (17) and Yang et al. (37). Briefly, the purified polysaccharide sample (1 mg) was hydrolyzed with $1 \mathrm{ml}$ of $2 \mathrm{M}$ trifluoroacetic acid at $120^{\circ} \mathrm{C}$ for 2 $\mathrm{h}$, derivatized with 1-phenyl-3-methyl-5-pyrazolone, and subsequently analyzed by high-performance liquid chromatography with a four-unit pump (Agilent Technologies, Wilmington, USA) and a Shim-pak VP-ODS column $(4.6 \times$ $150 \mathrm{~mm}$ ) with detection by absorbance monitoring at $245 \mathrm{~nm}$.
The mobile phase consisted of $82 \%$ sodium phosphate $(50 \mathrm{mM}$, $\mathrm{pH} 7.0)$ and $18 \%$ acetonitrile (v/v), and the sample was eluted

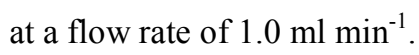

The molecular mass of EPS was determined by gel filtration chromatography of the isolated EPS on a Sepharose CL-6B column $(1.6 \times 100 \mathrm{~cm})$, calibrated with dextran standards (Mw 2000, 500, 150, 70 and 40 kDa; Fluka Chemie $\mathrm{GmbH}$, Buchs, Switzerland), and eluted with $0.9 \% \mathrm{NaCl}$ at a flow rate of $0.16 \mathrm{ml} \mathrm{min}^{-1}$. The carbohydrate content of each fraction $(3.2 \mathrm{ml})$ was determined by the phenol-sulfuric acid assay (12) using glucose as a standard.

The viscosity of the aqueous solution of the purified EPS was determined using an AR-500 dynamic rheometer (TA Instruments, USA) by a method described by Yang et al. (38). A $1 \%(\mathrm{w} / \mathrm{v})$ solution of EPS was prepared by dissolving the freeze-dried polysaccharide material in deionized water. The viscometry measurements were performed at $20^{\circ} \mathrm{C}$ with increasing shear rates up to $300 \mathrm{~s}^{-1}$.

\section{Statistical analysis}

All fermentations were carried out in duplicate independent experiments. For quantitative determination of EPS, bacterial counts and titratable acidity, samples were withdrawn in duplicate, and the results are presented as a mean \pm standard error.

\section{RESULTS AND DISCUSSION}

\section{Effects of initial pH on EPS production}

As shown in Figure 1b, S. thermophilus ST1 showed a similar growth pattern at all $\mathrm{pH}$ levels tested, growing fast during the first $8 \mathrm{~h}$ and then entering stationary phase. However, at $\mathrm{pH}$ 5.0, the bacterial growth was poor, showing low bacterial counts with only slight decrease in $\mathrm{pH}$ during the growth.

Figure 1a shows that EPS production by S. thermophilus ST1 was clearly affected by the initial $\mathrm{pH}$ of the medium. At 
$\mathrm{pH} 6.5$, the EPS production increased rapidly during the first $16 \mathrm{~h}$ of growth, and reached a maximal EPS yield of $45.10 \mathrm{mg}$ $\mathrm{l}^{-1}$ at $24 \mathrm{~h}$. Comparatively, the strain produced less EPS at $\mathrm{pH}$ 5.0, 6.0 and 7.0 with a maximal yield at $40 \mathrm{~h}, 11.47 \mathrm{mg} \mathrm{l}^{-1}$, $35.58 \mathrm{mg} \mathrm{l}^{-1}$ and $18.53 \mathrm{mg}^{-1}$, respectively. The decreased EPS production, e.g. at $\mathrm{pH} 5.0$ by $S$. thermophilus ST1 could be explained by the high acidity of the medium that might cause acid stress to the cells (35). EPS-producing bacteria could protect the cells from environmental stress by controlling the release of the produced EPS (1), and in some cases by forming a capsule around the cells (29). Similar findings were also reported for the LAB strains from kefir grains with $\mathrm{pH}$ dependent production of an extracellular Kefiran; acidic stress $(\mathrm{pH}$ 4.5-4.9) caused a drastic decrease in the Kefiran production (4)

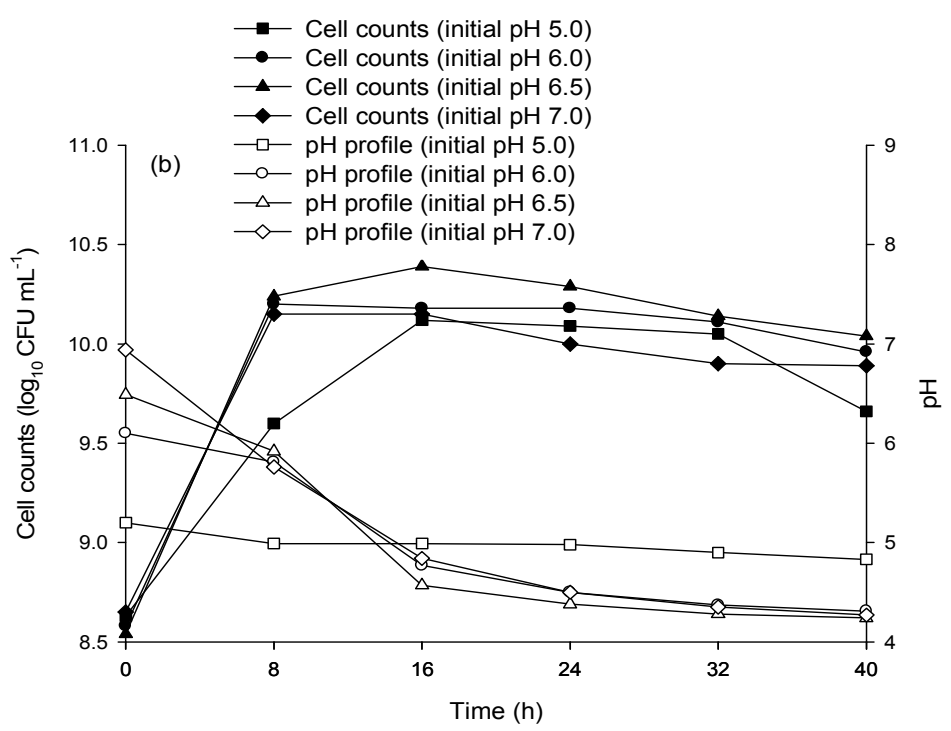

Figure 1. Effect of the initial $\mathrm{pH}$ of medium on growth and EPS production by S. thermophilus ST1. Cultivation of strain ST1 in skim milk at $37^{\circ} \mathrm{C}$ and at different initial $\mathrm{pH}$ was monitored by the yield of EPS (a), the cell counts and the pH profile of the culture (b).

\section{Effect of temperature on EPS production}

The effect of temperature on EPS production by $S$. thermophilus ST1 was investigated with skim milk at 30, 37 and $42^{\circ} \mathrm{C}$ (Figure $2 \mathrm{a}$ and $2 \mathrm{~b}$ ). The results showed that at the optimal temperature $\left(42^{\circ} \mathrm{C}\right)$ for growth, this strain produced the highest amount of EPS with the maximal yield of $59.06 \mathrm{mg} \mathrm{l}^{-1}$ at $32 \mathrm{~h}$. The strain produced much less EPS at 30 and $37^{\circ} \mathrm{C}$ with the maximal yields of $21.47 \mathrm{mg} \mathrm{l}^{-1}$ at $24 \mathrm{~h}$ and $34.35 \mathrm{mg}^{-1}$ at $16 \mathrm{~h}$, respectively.

Studies on the kinetics of EPS synthesis by S. thermophilus
ST1 at different temperatures (Figure 2) and at different pHs (Figure 1) indicated that EPS production by $S$. thermophilus ST1 was growth-linked. The optimal conditions such as temperature $\left(42^{\circ} \mathrm{C}\right)$ and $\mathrm{pH}(6.5)$ for the growth of $S$. thermophilus ST1 were favorable for its EPS production. However, there were also reports that optimal conditions for EPS production by some LAB strains were different from those for their optimal growth (13). A number of LAB strains were shown to produce more EPS at a lower temperature for their optimal growth (19). Acidic stress that inhibited bacterial growth could stimulate EPS production by 
some LAB strains (39). EPS production has been considered a mechanism of bacterial self-protection against unfavorable environmental factors, such as dehydration, high acidity and phage attack, among others (30).
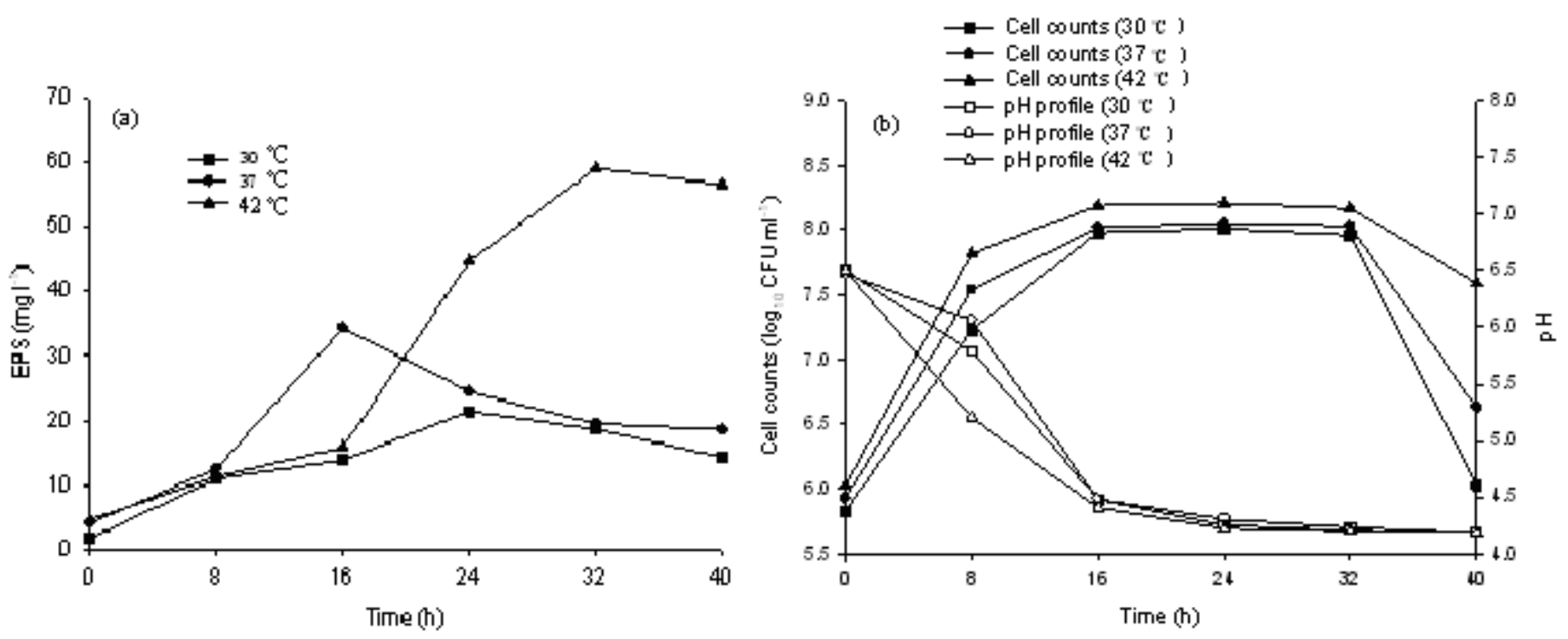

Figure 2. Effect of temperature on growth and EPS production by S. thermophilus ST1. Cultivation of strain ST1 in skim milk at different temperature was monitored by the yield of EPS (a), the cell counts and the pH profile of the culture (b).

\section{Effect of supplementation with carbohydrates on EPS production}

The effect of supplementation with different carbohydrates (glucose, lactose, sucrose, galactose, fructose) on EPS formation by $S$. thermophilus ST1 grown in skim milk for $32 \mathrm{~h}$ at $42^{\circ} \mathrm{C}$ is shown in Table 1 . There was an increased bacterial growth, achieving populations of around log 8.2 CFU $\mathrm{ml}^{-1}$ at $32 \mathrm{~h}$, when $2 \%(\mathrm{w} / \mathrm{v})$ of fructose, lactose, glucose or sucrose were added to the skim milk, whereas the control reached $\log 8.01 \mathrm{CFU} \mathrm{ml}^{-1}$ at $32 \mathrm{~h}$. The addition of any of the sugars to the culture resulted in a significant increase in EPS yield, showing values of $64.52 \mathrm{mg} \mathrm{l}^{-1}, 66.39 \mathrm{mg} \mathrm{l}^{-1}, 69.35 \mathrm{mg} \mathrm{l}$ ${ }^{-1}$, and $73.28 \mathrm{mg}^{-1}$, respectively, with the addition of fructose, lactose, glucose, and sucrose, whereas the EPS yield obtained for the control was of $45.63 \mathrm{mg}^{-1}$ at $32 \mathrm{~h}$. The EPS yield was also higher with galactose $\left(60.93 \mathrm{mg} \mathrm{l}^{-1}\right)$, when compared to that of the control, although no obvious increased bacterial growth (log $7.98 \mathrm{CFU} \mathrm{ml}^{-1}$ ) was observed with this sugar.

The effect of carbon source on growth and EPS production by $\mathrm{LAB}$ was reported to be dependent on the specific strain, the type of sugar, and the properties of the cell carbohydrate metabolism (24). Previously, glucose, lactose, and galactose were found to be suitable carbon sources for EPS synthesis by L. helveticus ATCC 15807 in a chemically defined medium. Nevertheless, this strain displayed much less growth with galactose than with glucose or lactose (34). L. casei CG11 was grown well with galactose, glucose or sucrose in a basal minimum medium, but it produced much less EPS with galactose than with the other sugars (2). Inhibition of the activity of some key enzymes for EPS synthesis might decrease EPS synthesis, as shown for L. sakei 0-1 when this strain was grown on galactose, giving a low EPS yield (8). In the present study, supplementation with galactose stimulated EPS 
formation, but not the growth of $S$. thermophilus ST1, suggesting that most of the sugar is employed for EPS biosynthesis and little or none as an energy source for growth
(6). Further studies are needed to elucidate the mechanism involved in the different effect of carbohydrates on EPS synthesis by $S$. thermophilus ST1.

Table 1. Effect of supplementation in the skim milk medium with different carbon sources on the growth and EPS production by S. thermophilus $\mathrm{ST} 1$ grown at $42^{\circ} \mathrm{C}$ for $32 \mathrm{~h}^{\mathrm{a}}$

\begin{tabular}{llll}
\hline Medium & pH & $\begin{array}{l}\text { EPS } \\
\left(\mathbf{m g ~ l}^{\mathbf{1}}\right)\end{array}$ & $\begin{array}{l}\text { Cell counts } \\
\left(\mathbf{l o g}_{\mathbf{1 0}} \mathbf{C F U} \mathbf{~ m l}^{-\mathbf{1}}\right)\end{array}$ \\
\hline Skim milk & $4.20 \pm 0.03$ & $45.63 \pm 0.53$ & $8.03 \pm 0.02$ \\
Skim milk+2\% galactose & $4.45 \pm 0.06$ & $60.93 \pm 0.38$ & $8.03 \pm 0.05$ \\
Skim milk+2\% fructose & $4.24 \pm 0.01$ & $64.52 \pm 0.67$ & $8.25 \pm 0.08$ \\
Skim milk+2\% lactose & $4.30 \pm 0.01$ & $66.39 \pm 0.29$ & $8.18 \pm 0.07$ \\
Skim milk+2\% glucose & $4.29 \pm 0.05$ & $69.35 \pm 0.78$ & $8.20 \pm 0.09$ \\
Skim milk+2\% sucrose & $4.32 \pm 0.07$ & $73.28 \pm 0.46$ & $8.23 \pm 0.11$ \\
\hline \multicolumn{2}{l}{ All the values are expressed as the means \pm standard deviations of duplicate measurements }
\end{tabular}

using the cultures at $32 \mathrm{~h}$ of growth.

\section{Effect of supplementation with WPC on EPS production}

Figure 3 shows that supplementation of the skim milk with $0.5 \%(\mathrm{w} / \mathrm{v})$ WPC increased both the bacterial growth and the EPS production by $S$. thermophilus ST1. Throughout fermentation, both the bacterial counts and the EPS yields maintained at higher levels with the supplementation of WPC than those of the control. At $24 \mathrm{~h}$, the maximal amount of EPS $\left(82.70 \mathrm{mg} \mathrm{l}^{-1}\right)$ was produced with the supplementation of WPC, compared to $41.10 \mathrm{mg} \mathrm{l}^{-1}$ observed for the control. At the end of fermentation, the EPS yield with the supplementation of WPC was $52.74 \%$ higher than that obtained without supplementation.

Milk was reported not to be a suitable medium for EPS synthesis by $S$. thermophilus, due to the absence of certain vitamins, peptides, and amino acids, essential for bacterial growth and EPS synthesis $(5,10,26,33)$. In addition, limited proteolytic activity and inefficient peptide transport mechanism of these strains also limit their growth rate (20). However, for some $S$. thermophilus strains that had the capability of catabolizing larger proteins, addition of yeast extract, peptone (14) or WPC (39) to milk was found to increase the growth and EPS synthesis by providing necessary peptides and amino acids for the cells (16). The results obtained in this study, regarding the increased growth and EPS production of $S$. thermophilus ST1 with the supplementation of WPC in skim milk were in agreement with these previous findings.

Figure 3 also shows that addition of $0.5 \%(\mathrm{w} / \mathrm{v})$ WPC to skim milk caused a delay on $\mathrm{pH}$ decrease during the initial $24 \mathrm{~h}$ fermentation, probably due to the buffering effect of WPC. Previous studies showed that partial replacement of skim milk with WPC could enhance the buffering capacity of yogurt, which caused a delay on $\mathrm{pH}$ decrease during yogurt production, resulting in an increased bacterial growth and EPS production $(18,32)$.

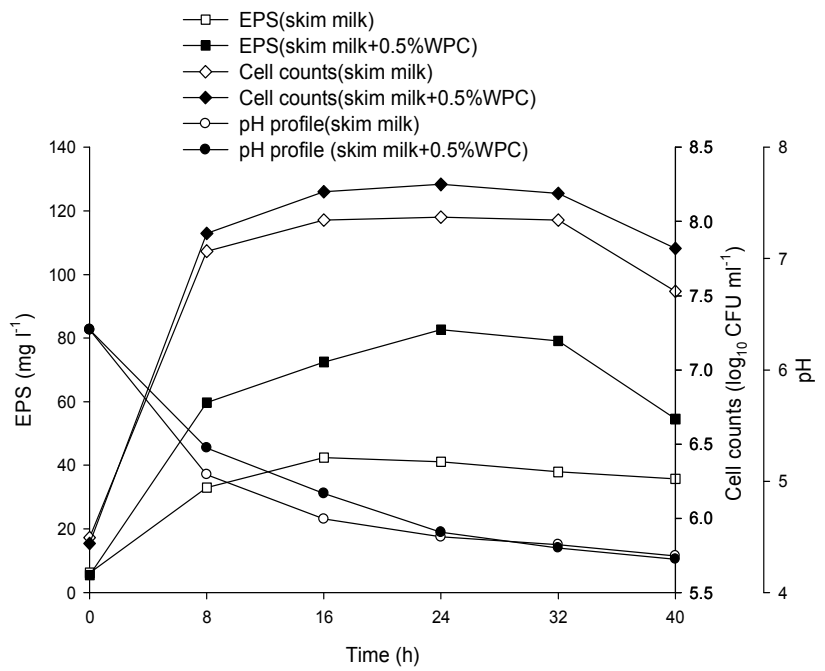

Figure 3. EPS production, cell counts and $\mathrm{pH}$ profile of the culture of $S$. thermophilus ST1 grown at $42^{\circ} \mathrm{C}$ in skim milk supplemented with WPC at $0.5 \%(\mathrm{w} / \mathrm{v})$. 


\section{EPS isolation and characterization}

S. thermophilus ST1 produced a maximal amount of 135.80 $\mathrm{mg}^{-1}$ of EPS, when this strain was grown under the optimal conditions determined above, i.e. $42^{\circ} \mathrm{C}$ in skim milk supplemented with $2 \%(\mathrm{w} / \mathrm{v})$ sucrose and $0.5 \%(\mathrm{w} / \mathrm{v})$ WPC. The EPS isolated from the above cultures was purified to homogeneity by anion exchange chromatography on DEAE-Cellulose and gel filtration chromatography on Sepharose CL-6B, showing a single peak for the polysaccharide (Figure 4). The EPS of S. thermophilus ST1 was shown to be a neutral polysaccharide, since it was not adsorbed onto the DEAE-Cellulose anion exchange column eluted with water. Monosaccharide analysis by HPLC of the purified EPS produced by $S$. thermophilus ST1 showed two distinct peaks, corresponding to glucose and galactose in a molar ratio of 2:1 (Figure 5). Previously, several S. thermophilus strains, such as SFi39 (22), EU20 (23), STD, CH101 (11), and THS (25) were also found to produce EPSs containing glucose and galactose, but in different molar ratios of the monosaccharides. Additional sugar components, such as rhamnose, ribose, fucose or $N$-acetyl-Dgalactosamine were also found in the EPSs produced by $S$. thermophilus strains $(1,30)$. The molecular mass of the EPS produced by $S$. thermophilus ST1 was determined to be $3.97 \times 10^{6}$ Da. The molecular mass of heteropolysaccharides produced by LAB usually ranges from $4.0 \times 10^{4} \mathrm{Da}$ to $6.0 \times 10^{6} \mathrm{Da}(30)$.

The aqueous solution of the purified EPS $(1 \%, w / v)$ of $S$. thermophilus ST1 gave relatively high viscosity, i.e. $406.6 \mathrm{mPa} . \mathrm{s}$ at a shear rate of $4.46 \mathrm{~s}^{-1}$. The drastic decrease in viscosity of the EPS solution from 406.6 to $24.16 \mathrm{mPa}$.s, with increasing shear rate from 4.46 to $279.3 \mathrm{~s}^{-1}$ clearly showed the non-Newtonian behavior (shear-thinning) of the EPS solution (Figure 6).

In summary, EPS production by S. thermophilus ST1 was dependent on cultural conditions, such as growth temperature, the initial $\mathrm{pH}$ of growth medium, and composition of the medium, such as carbon and nitrogen sources. Conditions suitable for growth of S. thermophilus ST1 were found to be favorable for its EPS production. Optimization of cultural conditions for $S$. thermophilus ST1 resulted in a significant increase in EPS production by $130 \%$. The viscous nature of the EPS of $S$. thermophilus ST1 as shown in this study indicated the possible application of this EPS-producing strain in the improvement of physical properties of fermented milk products.

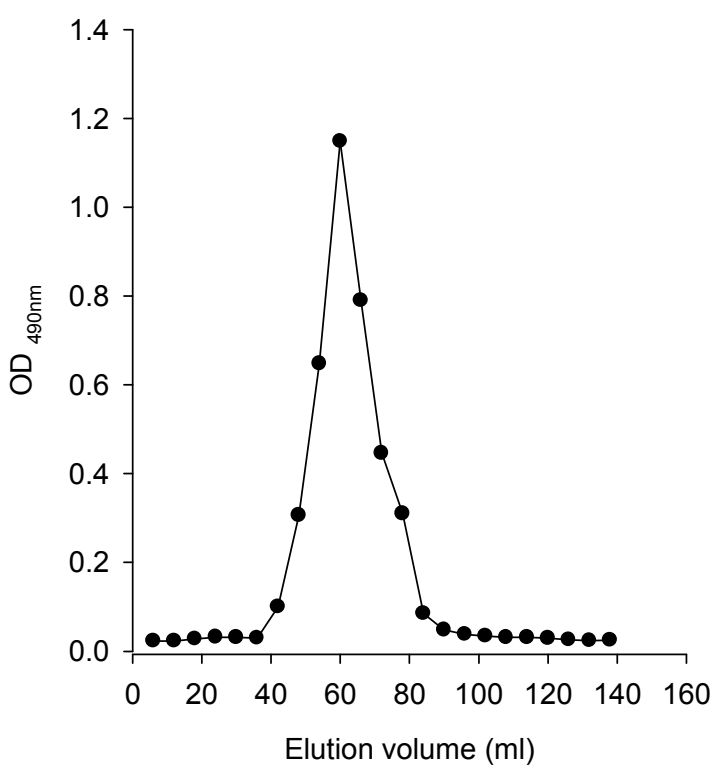

Figure 4. Purification of the EPS produced by S. thermophilus ST1 by gel filtration chromatography on Sepharose CL-6B, showing a single peak of the polysaccharide.

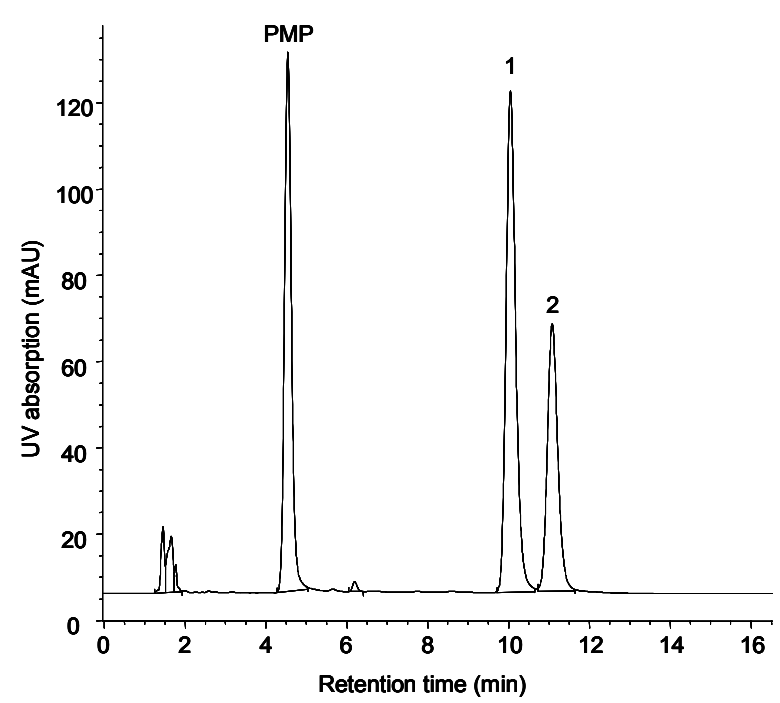

Figure 5. Monosaccharide analysis of the purified EPS sample by HPLC of the PMP derivatives of the acid hydrolysate of EPS, showing two peaks for glucose (peak 1) and galactose (peak 2). PMP, 1-phenyl-3-methyl-5-pyrazolone. 


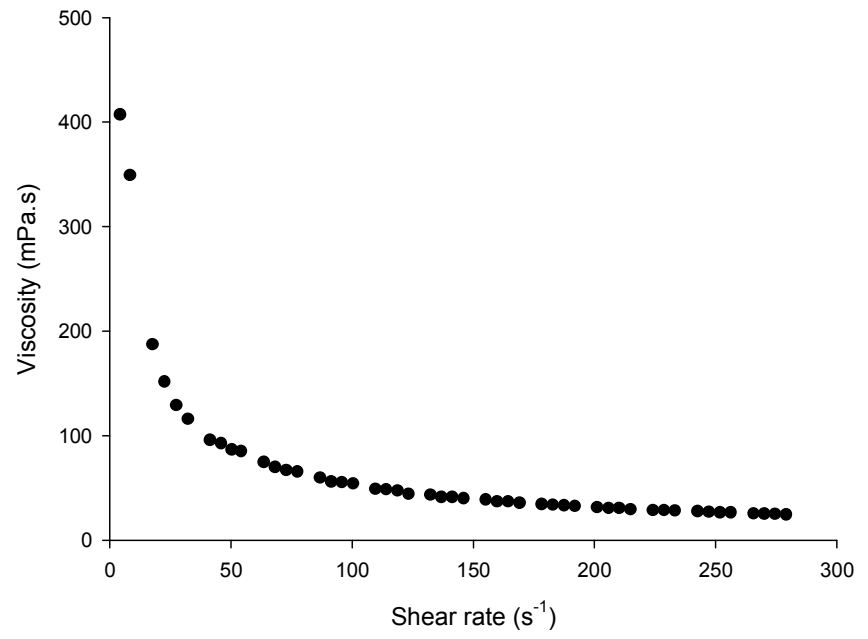

Figure 6. Viscosity-shear rate profile of $1 \%(\mathrm{w} / \mathrm{v})$ aqueous solution of the EPS produced by S. thermophilus ST1 at $20^{\circ} \mathrm{C}$.

\section{ACKNOWLEDGEMENTS}

The financial support for this work from National 863 Program (2006AA10Z306), The Earmarked Fund for Modern Agro-industrial Technology Research Systems in China (Nycytx-05-02) and Natural Science Foundation of China (30670057) is gratefully acknowledged.

\section{REFERENCES}

1. Broadbent, J.R.; McMahon, D.J.; Welker D.L.; Oberg, C.J.; Moineau, S. (2003). Biochemistry, genetics, and applications of exopolysaccharide production in Streptococcus thermophilus: A review. J. Dairy. Sci. $86,407-423$.

2. Cerning, J.; Renard, C.M.G.C.; Thibault, J.F.; Bouillanne, C.; Landon, M., Desmazeaud, M.; Topisirovic, L. (1994). Carbon source requirements for exopolysaccharide production by Lactobacillus casei CG11 and partial structure analysis of the polymer. Appl. Envir. Microbiol. 60,3914-3919.

3. Cerning, J. (1995). Production of exopolysaccharides by lactic acid bacteria and dairy propionibacteria. Dairy. Sci. Technol. 75,463-472.

4. Cheirrsilp, B.; Shimizu, H.; Shioya, S. (2001). Modelling and optimisation of environmental conditions for kefiran production by Lactobacillus kefiranofaciens. Appl. Microbiol. Biotechnol. 57,639-646.

5. Courtin, P.; Monnet, V.; Rul, F. (2002). Cell-wall proteinases PrtS and
PrtB have a different role in Streptococcus thermophilus/Lactobacillus bulgaricus mixed cultures in milk. Microbiology. 148,3413-3421.

6. Degeest, B.; De Vuyst, L. (1999). Indication that the nitrogen source influences both amount and size of exopolysaccharides produced by Streptococcus thermophilus LY03 and modelling of the bacterial growth and exopolysaccharide production in a complex medium. Appl. Environ. Microbiol. 65,2863-2870.

7. Degeest, B.; De Vuyst, L. (2000). Correlation of activities of the enzymes $\alpha$-phosphoglucomutase, UDP-galactose 4-epimerase, and UDPglucose pyrophosphorylase with exopolysaccharide biosynthesis by Streptococcus thermophilus LY03. Appl. Environ. Microbiol. 66,35193527.

8. Degeest, B.; Janssens, B.; De Vuyst, L. (2001). Exopolysaccharide (EPS) biosynthesis by Lactobacillus. sakei 0-1: production kinetics, enzyme activities and EPS yields. J. Appl. Microbiol. 91,470-477.

9. De Vuyst, L.; Degeest, B. (1999). Heteropolysaccharides from lactic acid bacteria. FEMS. Microbiol. Rev. 23,153-177.

10. De Vuyst, L.; Vanderverken, F.; Van de Van, S.; Degeest, B. (1998). Production by and isolation of exopolysaccharides from Streptococcus thermophilus grown in a milk medium and evidence for their growthassociated biosynthesis. J. Appl. Microbiol. 84,1059-1068.

11. De Vuyst, L.; Zamfir, M.; Mozzi, F.; Adriany, T.; Marshall, V.; Degeest, B.; Vaningelgem, F. (2003). Exopolysaccharide-producing Streptococcus thermophilus strains as functional starter cultures in the production of fermented milks. Int. Dairy. J. 13,707-717.

12. Dubois, M.; Gilles, K.A.; Hamilton, J.K.; Rebers, P.A.; Smith, F. (1956). Colorimetric method for determination of sugars and related substances. Anal. Chem. 28,350-356.

13. Gamar, L.; Blondeau. K.; Simonet, J.M. (1997). Physiological approach to extracellular polysaccharide production by Lactobacillus rhamnosus strain C83. J. Appl. Microbiol. 83,281-287.

14. Gorret, N.J.; Maubois, L.; Engasser, J.M.; Ghoul, M. (2001). Study of the effects of temperature, $\mathrm{pH}$ and yeast extract on growth and exopolysaccharide production by Propionibacterium acidi-propionici on milk microfiltrate using a response surface methodology. J. Appl. Microbiol. 90,788-796.

15. Grobben, G.J.; Smith, M.R.; Sikkema, J.; De Bont, J.A.M. (1996). Influence of fructose and glucose on the production of exopolysaccharides and the activities of enzymes involved in the sugar metabolism and the synthesis of sugar nucleotides in Lactobacillus delbrueckii subsp. bulgaricus NCFB 2772. Appl. Microbiol. Biotechnol. 46,279-284.

16. Grobben, G.J.; Chin-Joe, I.; Kitzen, V.A.; Boels, I.C.; Boer, F.; Sikkema, J.; Smith, M.R.; De Bont, J.A.M. (1998). Enhancement of exopolysaccharide production by Lactobacillus delbrueckii subsp bulgaricus NCFB 2772 with a simplified defined medium. Appl. Microbiol. Biotechnol. 64,1333-1337. 
17. Honda, S.; Akao, E.; Suzuki, S.; Okuda, M.; Kakehi, K.; Nakamura, J. (1989). High-performance liquid chromatography of reducing carbohydrates as strongly ultraviolet-absorbing and electrochemically sensitive 1-phenyl-3-methyl-5-pyrazolone derivatives. Anal. Biochem. $180,351-357$.

18. Kailasapathy, K.; Supriadi, D.; Hourigan, J.A. (1996). Effect of partially replacing skim milk powder with whey protein concentrate on buffering capacity of yoghurt. Aust. J. Dairy. Tech. 51,89-93.

19. Kimmel, S.A.; Roberts, R.F.; Ziegler, G.R. (1998). Optimization of exopolysaccharide production by Lactobacillus delbrueckii subsp. bulgaricus RR grown in a semidefined medium. Appl. Envir. Microbiol. 64,659-664.

20. Letort, C.; Nardi, M.; Garault, P.; Monnet, V.; Juillard, V. (2002). Casein utilization by Streptococcus thermophilus results in a diauxic growth in milk. Appl. Environ. Microbiol. 68,3162-3165.

21. Looijesteijn, P.J.; Boels, I.C.; Kleerebezem, M.; Hugenholtz, J. (1999). Regulation of exopolysaccharide production by Lactococcus lactis subsp. cremoris by the sugar source. Appl. Environ. Microbiol. 65,5003-5008.

22. Lemoine, J.; Chirat, F.; Wieruszeski, J.M.; Strecker, G.; Favre, N.; Neeser, J.R. (1997). Structural characterisation of the exocellular polysaccharides produced by Streptococcus thermophilus Sfi39 and Sfi12. Appl. Environ. Microbiol. 63,3512-3518.

23. Marshall, V.M.; Dunn, H.; Elvin, M.; McLay, N.; Gu, Y.; Laws, A.P. (2001). Structural characterisation of the exopolysaccharide produced by Streptococcus thermophilus EU20. Carbohydr. Res. 331, 413-422.

24. Nicolaus, B.; Schiano, M.V.; Lama, L.; Poli, A.; Gambacorta, A. (2004). Polysaccharides from extremophilic microorganisms. Origins. Life. Evol. Biospheres. 34,159-169.

25. Nordmark, E.L.; Yang, Z.; Huttunen, E.; Widmalm, G. (2005). Structural studies of an exopolysaccharide produced by Streptococcus thermophilus THS. Biomacromolecules. 6,105-108.

26. Pailin, T.; Kang, D.H.; Schmidt, K.; Fung, D.Y.C. (2001). Detection of extracellular proteinase in EPS-producing lactic acid bacteria cultures on skim milk agar. Lett. Appl. Microbiol. 33,45-49.

27. Petry, S.; Furlan, S.; Crepeau, M.J.; Cerning, J.; Desmazeaud, M. (2000). Factors affecting exocellular polysaccharide production by Lactobacillus delbrueckii subsp. bulgaricus grown in a chemically defined medium. Appl. Environ. Microbiol. 66,3427-3431.

28. Philippe, D.; Beat, M. (2001). Applications of exopolysaccharides in the dairy industry. Int. Dairy. J. 11,759-768.

29. Roberts, I.S. (1996). The biochemistry and genetics of capsular polysaccharide production in bacteria. Annu. Rev. Microbiol. 50,285315 .

30. Ruas-Madiedo, P.; Hugenholtz, J; Pieternela, Z. (2002). An overview of the functionality of exopolysaccharides produced by lactic acid bacteria. Int. Dairy. J. 12,163-171.

31. Sanni, A.I.; Onilude, A.A.; Ogunbanwo, S.T.; Fadahunsi, I.F.; Afolabi, R.O. (2004). Production of exopolysaccharides by lactic acid bacteria isolated from traditional fermented foods in Nigeria. Eur. Food. Res. Technol. 214,405-407.

32. Schkoda, P. (2003). Membrane filtration-new applications in the manufacture of fermented dairy products. Swiss. Dairy. Food. 6,184194.

33. Shabhal, S.; Hemme, D.; Desmazeaud, M. (1991). High cell wallassociated proteinase activity of some Streptococcus thermophilus strains (H-strains) correlated with a high acidification rate in milk. Orig. artic. 71,351-357.

34. Torino, M.I.; Taranto, M.P.; Sesma, F.; Font, D.V.G. (2001). Heterofermentative pattern and exopolysaccharide production by Lactobacillus helveticus ATCC 15807 in response to environmental pH. J. Appl. Microbiol. 91,846-852.

35. Vaningelgem, F.; Zamfir, M.; Adriany, T.; De Vuyst, L. (2004). Fermentation conditions affecting the bacterial growth and exopolysaccharide production by Streptococcus thermophilus ST111 in milk-based medium. J. Appl. Microbiol. 97,1257-1273.

36. Vaningelgem, F.; Zamfir, M.; Mozzi, F.; Adriany, T.; Vancanneyt, M.; Swings, J.; De Vuyst, L. (2004). Biodiversity of exopolysaccharides produced by Streptococcus thermophilus strains is reflected in their production and their molecular and functional characteristics. Appl. Environ. Microbiol. 70,900-912.

37. Yang, X.; Zhao, Y.; Wang, Q.; Wang, H.; Mei, Q. (2005). Analysis of the monosaccharide components in Angelica polysaccharide by High Performance Liquid Chromatography. Anal. Sci. 21,1177-1180.

38. Yang, Z.; Huttunen, E.; Staaf, M.; Widmalm, G.; Tenhu, H. (1999). Separation, purification and characterisation of extracellular polysaccharides produced by slime-forming Lactococcus lactis ssp. cremoris strains. Int. Dairy. J. 9,631-638.

39. Zisu, B.; Shah, N.P. (2003). Effects of $\mathrm{pH}$, temperature, supplementation with whey protein concentrate, and adjunct cultures on the production of exopolysaccharides by Streptococcus thermophilus 1275. J. Dairy. Sci. $86,3405-3415$. 